\title{
Forest Habitats in the Nature Reserve ROSCI 0032 Rudariei Gorges
}

\author{
Ilinca M. IMBREA ${ }^{1}$, Ciprian CORPADE ${ }^{2}$, Ana-Maria CORPADE² ${ }^{2}$ Alma L. NICOLIN ${ }^{1 *}$ \\ ${ }^{1}$ Department of Botany, Banat's University of Agricultural Sciences and Veterinary Medicine „King \\ Michael I of Romania", Timișoara, Romania \\ ${ }^{2}$ Department of Geography Extensions, Babeș-Bolyai University, Faculty of Geography,Cluj-Napoca, \\ Romania \\ * corresponding author: alma.nicolin@gmail.com
}

Bulletin UASVM series Agriculture 73(2)/2016

Print ISSN 1843-5246; Electronic ISSN 1843-5386

DOI 10.15835/buasvmcn-agr: 12399

\begin{abstract}
The Rudăriei Gorges, named after the Rudărica rivulet, is close to the Eftimie Murgu village, also known by the name of Rudăria. It is located in south-west Romania, Caras-Severin County, Almăjului Depression. It is known both in Romania and abroad less for its flora, fauna and landscape features and most for its mill reserve, where water mills are still used by the natives. The paper has as purpose, establishment of forest habitats in the area of research. At the same time the work wants to clarify inconsistencies on the types of forest habitats reported to be present in accordance with the Standard Form of the site of community importance ROSCI0032 and habitats identified in the field. The methodology is specific to the identification and characterization of habitats. Field survey (during vegetation, March-October) showed that the vegetation in the area was mosaic-like, which hindered habitat mapping. Moreover, we have noticed differences between the habitats mentioned for the area (Standard Form) and those identified in the field. Thus, the Standard Form of ROSCI0032 Cheile Rudăriei mentions as existing in the area the habitat 91K0 - Illyrian Fagus sylvatica forests (Aremonio-Fagion), but in the field there were found no species representative for this type of habitat. According to our studies, the beech forests in the Rudăriei Gorges are part of the Habitat 9110 - Luzulo-Fagetum beech forests. Other new habitats described in the area and not mentioned in the Standard Form are 91E0* - Alluvial forests with Alnus glutinosa and Fraxinus excelsior (Alno-Padion, Alnion incanae, Salicion albae); 91M0 - Pannonian-Balkanic turkey oak - sessile oak forests. The habitat 9180* - TilioAcerion forests of slopes, screes and ravines, mentioned in the Standard Form, was confirmed in the field.
\end{abstract}

Keywords: forest habitats, Rudăriei Gorges, Nature Reserve.

\section{INTRODUCTION}

The Rudăriei Gorges Reserve conserves plant species and habitats characteristic to the rocks of South Banat, an area rich in thermophilous and subMediterranean species. The first comprehensive study of flora and vegetation was carried out by Peia in 1978. Studies later obtained highlight the evolution and changes occured over time (Nicolin et al., 2007, Imbrea et al., 2014). At present, the reserve Rudăriei Gorges is also a Natura 2000 Site: ROSCI0032 Cheile Rudăriei (by OM 1.964/2007) with an area of 300 ha.
As mentioned in previous studies (Imbrea et al., 2014), siliceous rocks dominate the Rudăriei Gorges. Their presence determines high differences between the vegetation of the area and the neighbouring protected areas known for the limey substrate and extended karst areas (Nerei Gorges, Caraşului Gorges, and Gârliştei Gorges). Similar geological formations can also be found further east, in the Almăjului Depression, in the Globului Gorges Nature Reserve. (Imbrea et al., 2007, Imbrea et al., 2008). 


\section{MATERIALS AND METHODS}

Plant associations have been described based on specific methodology (J. Braun - Blanquet, 1926; Borza and Boșcaiu, 1965). Framing habitats and their description was based on specific textbooks (Interpretation Manual of Natura 2000 Habitats in România, coord. Gafta and Mounford, 2008 and Habitats from România, Doniță et al., 2005).

\section{RESULTS AND DISCUSSION}

The strong mosaic-like aspect of vegetation and the nature of the geological substrate have made habitat mapping difficult; some of them, included in the Standard Form, were not found in the protected area actually. Thus, of the 2 types of protected forest habitats mentioned in the ROSCI0032 Standard Form Rudariei Gorges 9180* - Tilio-Acerion forests of slopes, screes and ravines and 91K0- Illyrian Fagus sylvatica forests (Aremonio-Fagion), only the former one was actually found in the field.

The habitat 9180* - Tilio-Acerion forests of slopes, screes and ravines is a protected habitat of community interest mentioned in the Standard Form. The habitat is represented by mixed forests made up of mixed species (Acer pseudoplatanus, Fraxinus excelsior, Ulmus glabra, Tilia cordata) on screes, abrupt rocky slopes or coarse colluviums on the slopes, particularly on limey substrata and on siliceous substrata (Tilio - Acerion Klika 1955). We can distinguish between a typical grouping of cold, moist stations (sciaphilous and meso-hygrophilous forests) generally dominated by sycamore maple (Acer pseudoplatanus) - suballiance Lunario - Acerenion, and another one, typical for dry, warm screes (xerothermophilous forests), generally dominated by lime trees (Tilia cordata, T. platyphyllos) - sub-alliance Tilio Acerenion (Gafta and Mountford Eds., 2008).

Among the species characteristic to this type of habitat are Acer pseudoplatanus, Actaea spicata, Fraxinus excelsior, Lunaria rediviva, Polystichum aculeatum, Taxus baccata, Ulmus glabra, Carpinus betulus, Corylus avellana, Quercus spp., Tilia cordata, and T. platyphyllos.

The habitat is present on generally abrupt slopes with variable exposition - mainly southern - with mobile scree or surface rock characterised by a good conservation state (Fig. 1). The slopes are hard to reach. Vegetal cover varied between $30 \%$ and $80-90 \%$. Flora composition is very variable, correlated with station features. There are frequent (sub) Mediterranean xerothermophilous species in both tree, shrub (Acer tataricum, Viburnum opulus, Rhamnus cathartica, Quercus cerris) and grass layer. The shrub layer is well developed with Sambucus nigra, Cornus sanguinea, Corylus avellana, Crataegus monogyna,

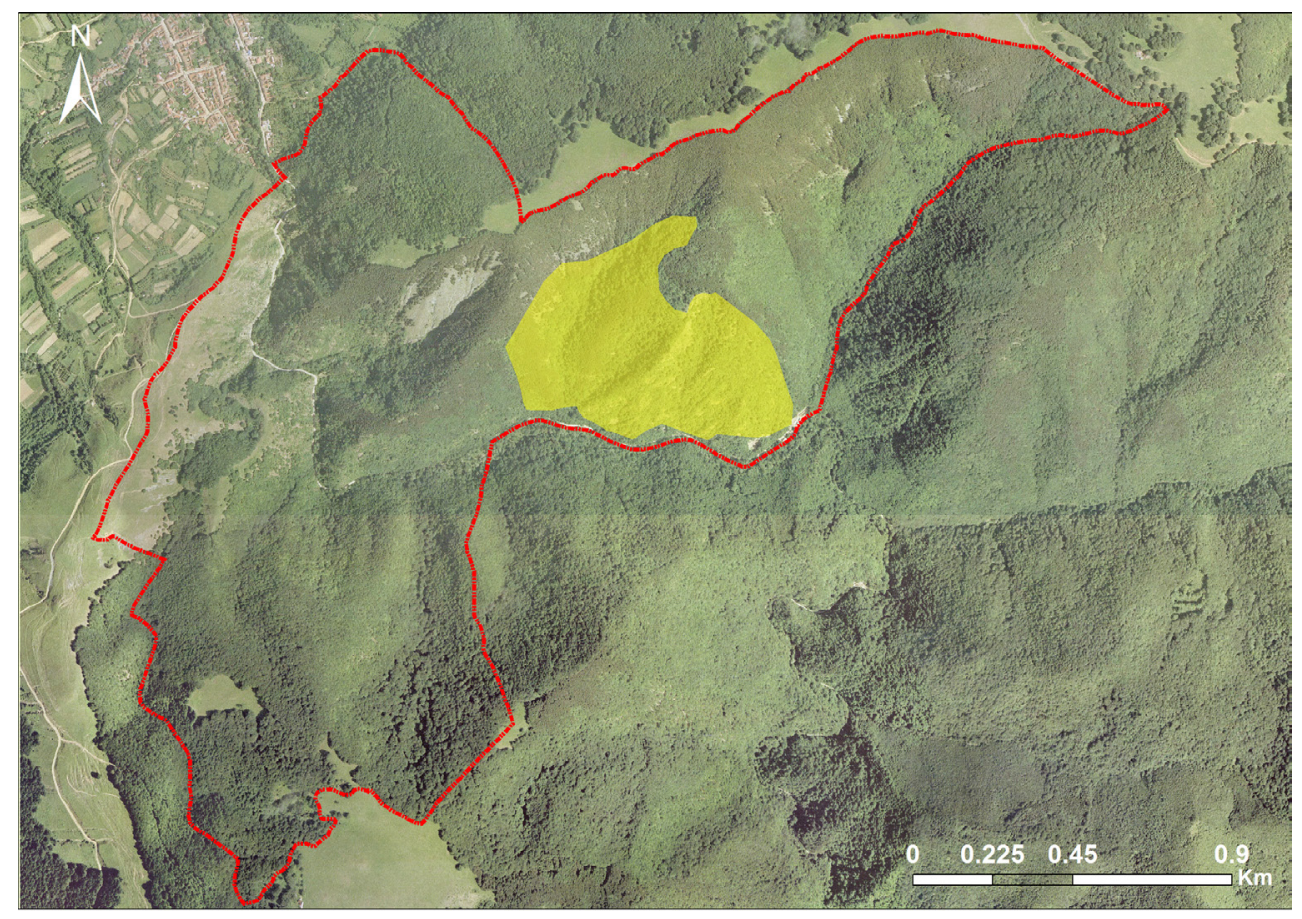

Fig. 1. Distribution of habitat $9180 *$ 
and Evonymus europaeus. The grass layer also covers numerous species characteristic to the neighbouring habitats. Because of the plantation in the area, the Austrian/black pine invades portions of this habitat, partially degrading it.

Habitat 91K0 - Illyric forests of Fagus sylvatica (Aremonio-Fagion) is characterised by high biodiversity due to the presence of such species as hellebore (Helleborus odorus), butcher's broom (Ruscus aculeatus), spineless butcher's broom (Ruscus hypoglossum), Turkish hazel/filbert (Corylus colurna), bastard agremony (Agremonia agrimonioides), widow flower (Knautia drymeia), primrose (Primula vulgaris), bigroot geranium (Geranium macrorrhizum). However, in the field, the most representative of these species have not been identified.

Though in south Banat (e.g., Nerei Gorges) this type of habitat rich in species is well represented, the beech forest in Rudăriei Gorges is remarkable due to its extremely low biodiversity with few species in the grass cover, together with the lack of the characteristic ones. The evenness of this forest is very high with beech (Fagus sylvatica) as exclusively dominant species.

Though this beech forest is low in species, it is remarkable due to its good conservation state and tree age. Long maintenance of beeches is also due to the difficulty to reach slopes. Slope exposition is mainly northern, which explains the presence of the beech at such low altitudes (up to $400 \mathrm{~m}$ ).

The analysis of the field data shows that these beech forests in Rudăriei Gorges match the Habitat 9110 - Beech forests of the LuzuloFagetum type. The grass species identifying this habitat are Festuca altissima, Luzula luzuloides and Deschampsia flexuosa.

In addition, the Romanian habitat manual (Gafta and Mountford (Eds.), 2008) mentions that Habitat $91 \mathrm{~K} 0$ is common to south-western Carpathians and Pannonian hills, in contact with or intertwined with medium-European beech forests from Habitats 9130, 9140 and 9150, therefore, together with mainly limey-substrate beech forests rich in species sometimes with increased hydric supply Asperulo-Fagetum, CephalantheroFagion.

It is only close to the Rudărica River Valley (towards the middle of the protected area) that, due to the high moisture level, those beech forests are richer in species - both woody and grassy. There, beech also shares its dominance with hornbeam (Carpinus betulus) or common oak (Quercus petraea) and forests tend to belong to Habitat 9130 (forests of the Asperulo-Fagetum type) and less to Habitat 91V0 (Dacian beech forests of the Symphyto-Fagion type). Though we can identify species of these habitats, their abundance is insignificant; the transition area is also reduced, which does not explain its grouping into another beech forest type.

In the Rudăriei Gorges, the substrate is mainly siliceous, hence the great differences in vegetal cover with neighbouring protected areas. Because of low altitude, fir and spruce are not present. Habitat 9110 is in contact with 91E0* (Alluvial forests of Alnus glutinosa and Fraxinus excelsior), on the riverbank, and with 9180* (Forests of Tilio-Acerion on the slopes, screes and ravines). In clearings, there is Pteridium aquilinum (bracken), an invasive fern characteristic for this type of habitat.

In this context, we have described three new forest habitats not mentioned in the Standard Form.

9110 - Luzulo-Fagetum beech forests. This habitat, not mentioned in the Standard Form, is a community habitat confirmed for most European standards. It covers all the southwestern part of the protected area on mainly northern expositions. This is the main forest body belonging to 9110, though more or less representative fragments can be found in other habitat types too.

The habitat has 2 sub-types; one sub-type characteristic to the studied area is 41.111 - Hill medium-European beech forests with Luzula: acidophilus forests of Fagus sylvatica in the low hercinic chains of Lorene, the hill floor of high hercinic chains in the Jura, at the fringe of the Alps, of the western sub-Pannonia and intra-Pannonia hills accompanied more or less by spontaneous conifers and, in general, with a mixture of Quercus petraea or, in certain cases, Quercus robur in the canopy. (Gafta and Mountford (Eds.), 2008; Thauront and Stallegger, 2008)

Among the species specific to the habitat are Fagus sylvatica, Abies alba, Picea abies, Luzula luzuloides, Polytrichum formosum and often Deschampsia flexuosa, Calamagrostis villosa, Vaccinium myrtillus, Pteridium aquilinum.

Natural habitat is well represented in the Rudăriei Gorges (100-150 ha), with a good con- 
servation state in south-west (Fig. 2). The forest is compact, even, with a low number of species characteristic for this type of habitat such as Festuca altissima, Luzula luzuloides, and Deschampsia flexuosa. Beech is mono-dominant on most of the area.

Another community-important habitat not mentioned in the Standard Form is $910^{*}$ - Alluvial forests with Alnus glutinosa and Fraxinus excelsior (Alno-Padion, Alnion incanae, Salicion albae). It develops along the Rudărica River and is dominated by common alder (Alnus glutinosa). At the exit from the gorges (towards the village), willow species are dominant.

It includes flooding meadow species such as Fraxinus excelsior and Alnus glutinosa characteristic to watercourses in the plain and hill areas of temperate and boreal Europe (44.3: Alno-Padion), meadow forests of Alnus incana characteristic to mountain and sub-mountainous rivers in the Alps and North Apennines (44.2: Alnion incanae) as well as the galleries made up of tall specimens of Salix alba, S. fragilis and Populus nigra characteristic to medium-European rives, in the submountainous, hill and plain areas (44.13: Salicion albae). All these types occur on heavy soils (in general, rich in alluvial deposits) periodically flooded by the raise of the river/rivulet level at least once a year, otherwise well drained and aerated when the water flow is low. The grass layer always includes numerous tall species (Filipendula ulmaria, Angelica sylvestris, Cardamine spp., Rumex sanguineus, Carex spp., and Cirsium oleraceum) and can contain different vernal geophytes such as Ranunculus ficaria, Anemone nemorosa, A. ranunculoides and Corydalis solida. (Gafta and Mountford (Eds.), 2008)

Most forests are in contact with moist meadows or with ravines forests (Tilio-Acerion). Sometimes there is a succession of beech forests towards Carpinion (Fig. 3).

Among the species characteristic to the tree layer are Alnus glutinosa, Alnus incana, Fraxinus excelsior, Populus nigra, Salix alba, S. fragilis, and Ulmus glabra. The grass layer contains Angelica sylvestris, Cardamine amara, C. pratensis, Carex acutiformis, C. pendula, C. remota, C. strigosa, $C$. sylvatica, Cirsium oleraceum, Equisetum telmateia, Equisetum spp., Filipendula ulmaria, Geranium sylvaticum, Geum rivale, Lycopus europaeus, Lysimachia nemorum, Rumex sanguineus, Stellaria nemorum, Urtica dioica.

In Romania, this habitat can be found along water courses all over the country, from plains to mountains, covering the flooding river and rivulet valleys, on lands with excess moisture that ensures good conditions for the development of hygrophilous or hydrophilous species.

In the protected area, the habitat is generally well preserved, though not expanded and covering

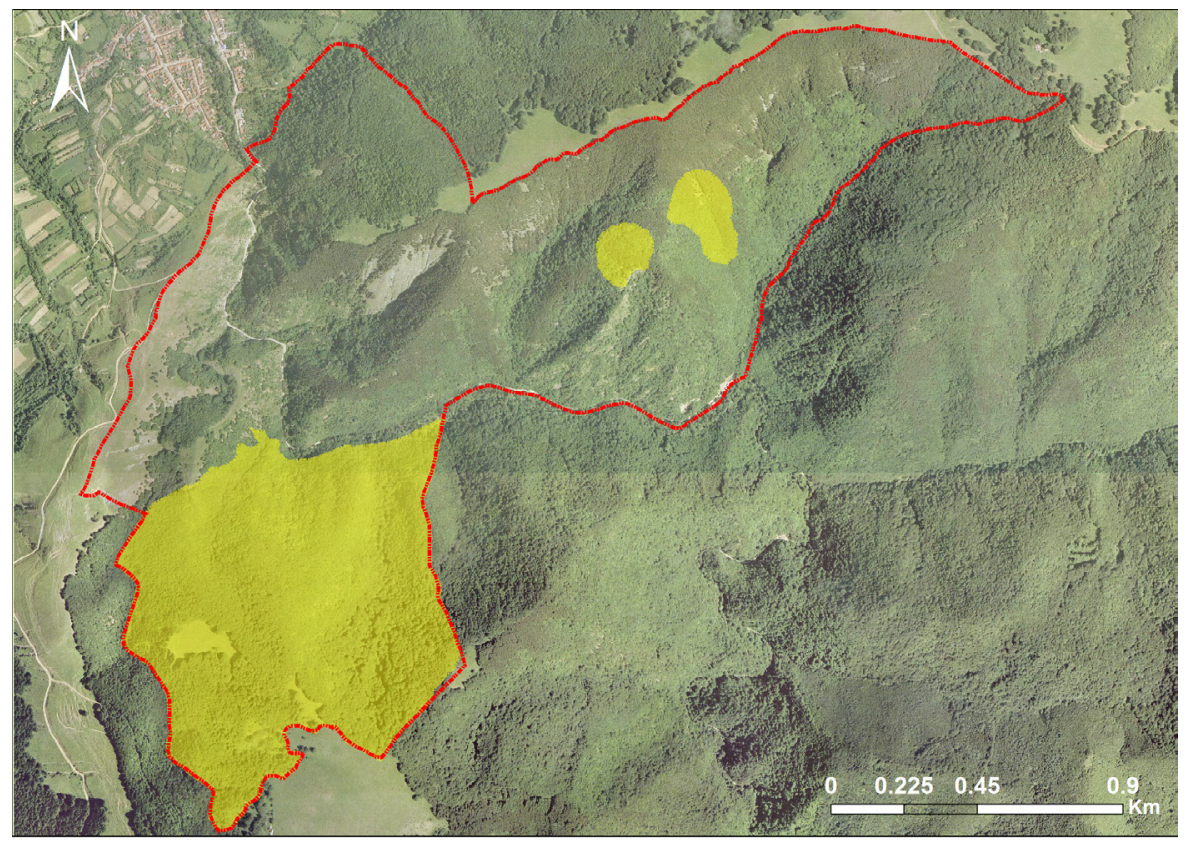

Fig. 2. Distribution of habitat 9110 


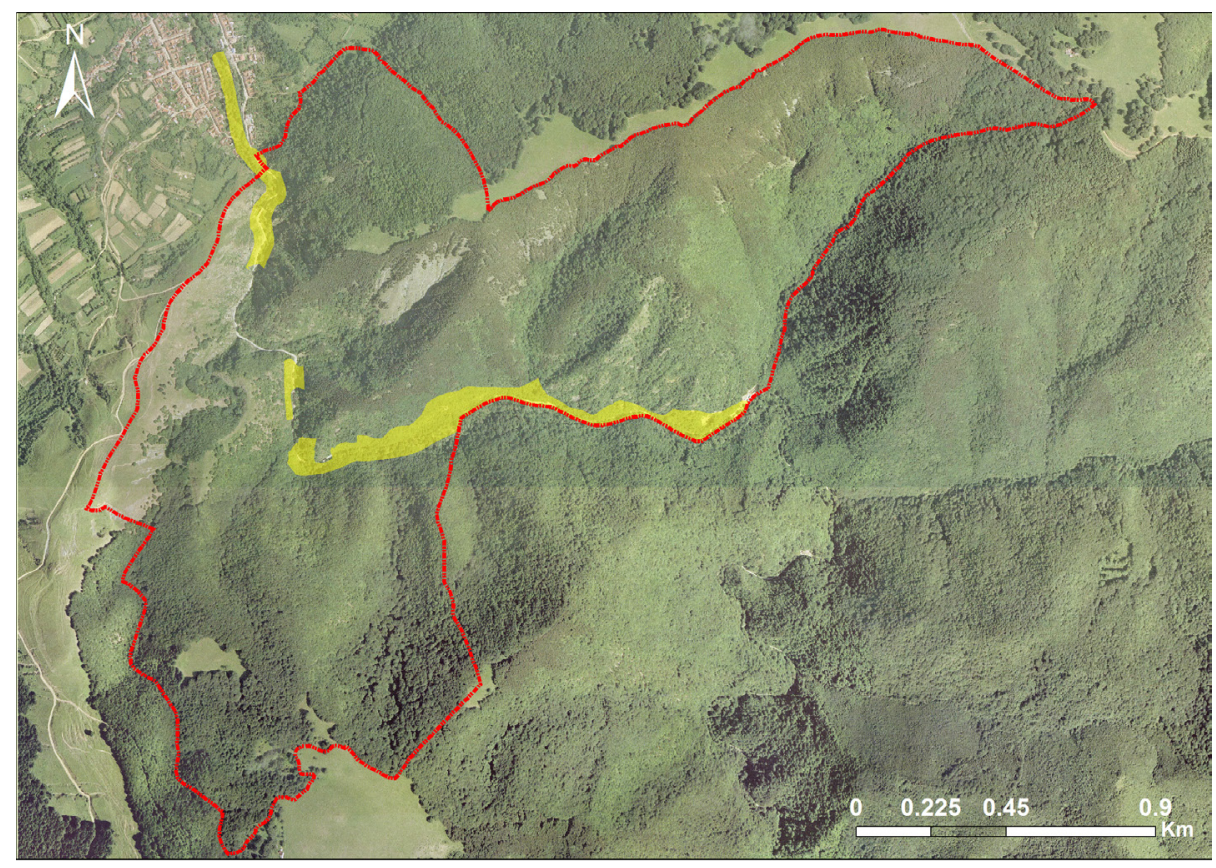

Fig. 3. Distribution of habitat 91E0*

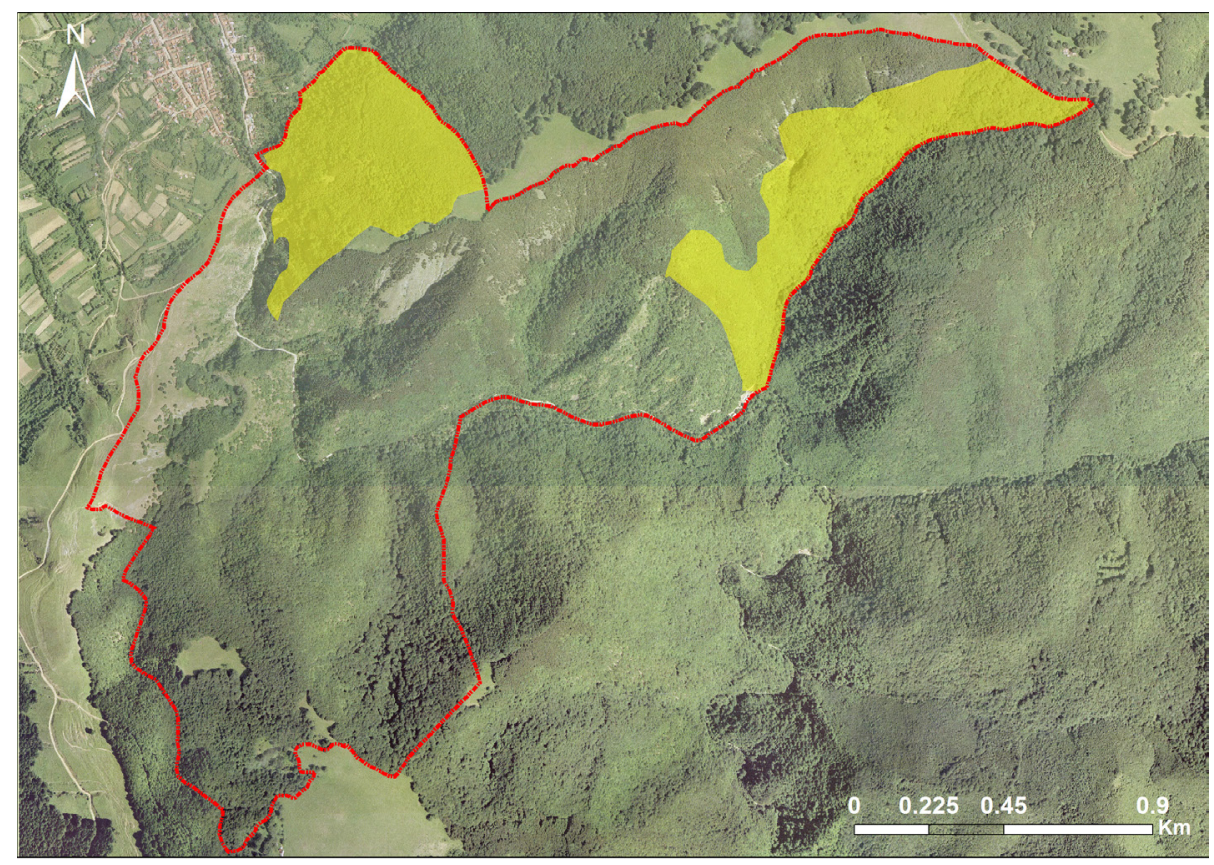

Fig. 4. Distribution of habitat $91 \mathrm{M} 0$

only the close neighbourhood of the river. Its flow is traditionally managed for providing water to the existing WWwatermills, making the landscape a characteristic one.

Towards the central area, at Poiana, there is a camping site rather crowded in summer. Tourism activities affect this surface because of soil setting (car parking), fireplaces and waste disposal. What worried most is tree cutting around the clearing or in its neighbourhood for firewood.

91M0 - Pannonian-Balkanic turkey oak sessile oak forests is a habitat covering southern, xerophilous slopes on frequently rocky or scree substratum in the east and north of the protected area, at lower altitudes (Fig. 4). 
The habitat includes sub-continental, xerothermophilous forests of Quercus cerris, Q. petraea or $Q$. frainetto and other species of deciduous oaks, local forests of $Q$. pedunculiflora or $Q$. virgiliana, specific to the Pannonia Plain, to the hills and plains of western and southern Romania, to the hill areas in the northern Balkans and in the supraMediterranean floor of continental north-eastern Greece, from supra-Mediterranean Anatolia and low altitude mountains with Acer tataricum. They are generally distributed at altitudes ranging from 250 to 600 (800) $\mathrm{m}$ above sea level and develope on different substrata such as lime, andesite, basalt, loess, clay, sand, etc., on brown, low acid, deep soils. (Gafta and Mountford (Eds.), 2008)

Characteristic species are Quercus petraea, $Q$. dalechampii, $Q$. polycarpa, $Q$. cerris, $Q$. frainetto, Acer tataricum, Carpinus orientalis, Fraxinus ornus, Tilia tomentosa, Ligustrum vulgare, Euonymus europaeus, Festuca heterophylla, Carex montana, Poa nemoralis, Potentilla alba, P. micrantha, Tanacetum corymbosum, Campanula persicifolia, Digitalis grandiflora, Vicia cassubica, Viscaria vulgaris, Lychnis coronaria, Achillea distans, A. nobilis, Silene nutans, S. viridiflora, Hieracium racemosum, $\mathrm{H}$. sabaudum, Galium schultesii, Lathyrus niger, Veratrum nigrum, Peucedanum oreoselinum, Helleborus odorus, Luzula forsteri, Carex praecox, Pulmonaria mollis, Melittis melissophyllum, Glechoma hirsuta, Geum urbanum, Genista tinctoria, Lithospermum purpurocaeruleum, Primula acaulis subsp. rubra, Galanthus plicatus.

Overall, the flora and vegetation of the Rudăriei Gorges is diverse also due to the types of biota. The conservation state of the habitats is, in some cases, very good.

\section{CONCLUSION}

In the present research work, we described new forest habitats, not mentioned in the Standard Form and explained the absence of some habitats mentioned to be present, clarifying things in this regard.

Priority habitat $9180 *$ was identified in the field, while priority habitat 91K0 (Illyric beech forests) was not re-confirmed in the protected area, though it is present in the neighbouring areas with limey substratum (Nerei Gorges - Beuşnița); this habitat was replaced by 9110 - Beech forests of the Luzulo-Fagetum type, characteristic to more acid soils with a vegetal cover poor in grass species.

In addition, we identified new forest habitats such as 9110 - Luzulo-Fagetum beech forests - a habitat well represented in the protected area, with a very good conservation state; 91E0* Alluvial forests with Alnus glutinosa and Fraxinus excelsior (Alno-Padion, Alnion incanae, Salicion albae)] - a habitat spread along the Rudărica Rivulet, covering relatively small areas; 91M0 - Pannonian-Balkanic turkey oak - sessile oak forests, a habitat developed in the vicinity of the habitat $9180^{*}$, dominated here and there by Oriental hornbeam on lands of forestry use.

Acknowledgements: This work has benefited by the financial support from the European Regional Development Fund (ERDF) under the Operational Programme Environment (Priority Axis 4) by the project "Developing the Management Plan of the Rudăriei Gorges protected area", identification code 36427, http://www.cheilerudariei.ro/.

\section{REFERENCES}

1. Doniță N, Popescu A, Paucă-Comănescu M, Mihăilescu S, Biriș I.A. (2005). Habitatele din România, Ed. Tehn. Silvică, Bucureşti.

2. Gafta D, Mountford O (coord.). (2008). Manual de interpretare a habitatelor Natura 2000 din România, Ed. Risoprint, Cluj-Napoca.

3. Imbrea IM, Nicolin AL, Florea M (2007). Studies concerning the rock flora in the Glob Gorges nature reserve, Lucr. Șt. Fac. Agricultură, 39 (2):539-546.

4. Imbrea IM, Nicolin A, Niculescu M (2008). Studies concerning the rock vegetation in the Cheile Globului Nature Reserve (South-Western Romania), Bulletin of University of Agricultural Sciences and Veterinary Medicine Cluj-Napoca, 65 (1):141-146.

5. Imbrea IM, Nicolin AL, Sorescu C, Corpade C and Buzila L (2014). Rock habitats in the Rudariei Gorges protected area, Research Journal of Agricultural Science 46 (2): 97 105.

6. Nicolin AL, Imbrea IM and Lațcu M (2007). Notes on the meadow vegetation in the Rudăria Gorges. Research Journal of Agricultural Science 39 (2): 571-576.

7. Peia P (1978). Vascular flora of the Almajului Depresion (Caraș-Severin County). Doctorat thesis. Univ. „Babes Bolyai" Cluj-Napoca.

8. Thauront M, Stallegger M (2008). Management of Natura 2000 habitats. 9110 Luzulo-Fagetum beech forests. European Commission. 